UDC 613.81/: 84-057.875: [61: 378.6

DOI: $10.21668 /$ health.risk/2017.1.09.eng

\title{
ASSESSMENT OF BASIC BEHAVIOURAL RISKS CONCERNING HEALTH OF STUDENTS ATTENDING MEDICAL UNIVERSITY
}

\section{T.N. Govyazina, Yu.A. Utochkin}

Perm State Medical University named after E.A. Wagner, 26 Petropavlovskaya Str., Perm, 614000, Russian Federation

We chose students from all the six years attending Medical and Prevention Faculty of Perm State Medical University named after academician E.A. Vagner as our research object. Our research goal was to examine and to assess basic behavioral risks which could cause health risks for students attending medical higher educational establishment. We applied a set of techniques in our work: information-bibliographic one (15 literature sources were studied, both periodicals and monographs), sociological one (467 students of Medical and Prevention Faculty were included into a one-time questioning, them all being an entire assembly), statistic one (we calculated relative values and mean values, as well as correlation coefficients). The research was performed in two steps; the first one was based on analyzing subjective evidence, namely, sociologic questioning results; in our second step we focused on examining pathologic damages as per medical examinations data as well as data on morbidity obtained from register of visits to a students' polyclinic.

Students' health is a significant parameter of a society intellectual potential; specific weight of students, both males and females, who take care of their health amounts to $60.0 \%$ and $96.5 \%$ correspondingly. $100 \%$ questioned girls and $58.3 \%$ boys consider their health to be "good". There are gender-based discrepancies in estimating one's health state in all sub-groups and as per all reasons for its preservation. $45 \%$ boys and $40 \%$ girls with quite different self-estimation of their health combine work and study. Students tend to have bad habits as they constantly drink alcohol and smoke. Despite availability of considerable volumes of information on diseases prevention students don't try to use this information and preserve their health. Medical students' lifestyle has such peculiarities as non-rational nutrition, insufficient physical, social and medical activity.

Key words: self-estimation of one's health, students, risk factors, nutrition, combining work and study, lifestyle, medical activity, medical aid organization, prevention, healthcare program, management.

In 20145.2 million students attended HEEs in Russia; 2.0 million of them received budgetary funding and didn't pay for their study. 4.0 million attended state and municipal educational establishments [8].

A higher educational establishment as a social institute is to educate a competent professional with good physical and mental health. Students are not only members of youth population group, but also they are intellectual potential of the whole society.

The higher is the significance of high professional education, the more often and more acute are its problems. Such problems include job placement for graduates (that's why a new position of a vice-chancellor responsible for graduates' job placement has been introduced in HEEs), family creation, and health of future professionals. Students' health can predict life quality for labor population in this or that region.

All factors significant for students' health can be divided into three groups: 1) socialhygienic ones, 2) medical-biological ones, 3) psychological ones.

To justify any management decisions, for example creation of health-preserving programs in a HEE, we need to study basic

(C) Govyazina T.N., Utochkin Yu.A., 2017

Tatyana N. Govyazina - Candidate of Medical Sciences, associate professor at Public Health and Healthcare Department (e-mail: super.oziz@yandex.ru; tel.: +7 (342) 233-23-36).

Yuriy A. Utochkin - Candidate of Medical Sciences, associate professor at Public Health and Healthcare Department (e-mail: super.oziz@yandex.ru; tel.: +7 (342) 233-23-36). 
parameters of students' health, namely morbidity (as per medical health appealability and medical examinations data), disability, medical-demographic indices, and physical development [15].

Self-assessment of one's health is a significant parameter of a person's health. It is very important to promote self-preserving behavior among students attending medical HEEs where a lot of attention in the educational process is paid to prevention issues among population (patients).

Students, just like the whole RF population, don't' think their health to be a basic value. Health self-assessment is an analysis of physical and mental health; it determines a person's behavior. I.V. Zhuravleva et al. [5, 6] state that self-assessment can be used as a health parameter. Researchers believe there is a high correlation between self-assessment and actual data taken from medical documents.

Academic load for students attending medical HEEs is on average 2 times higher than for students of other HEEs. Duration and educational specificity make high demands to their health state.

Health self-assessment can depend on the following factors: sex, age, educational status, territory of living, occupation, social and economic conditions in a region $[9,10]$

D.I. Kicha and M.I. Panachina divide all social and hygienic studies of students' problems in our country into four stages:

I stage. 20-30-ties of the XX century. Creation of organizational and methodical grounds for research of students;

II stage. 40-50-ties. Study and determination of standards for youth physical development;

III stage. 60-80-ties. Scientists started to examine students' lifestyle, nutrition and morbidity;

IV stage. Since the beginning of 90-ties a lot of research has been dedicated to studying health and, in particular, physical development [7].

Nowadays all research focuses not only on examining risk factors but also on giving grounds for students' health preservation programs.

Studying data on HEE students health helped us to determine certain regularities:

- when entering a HEE, applicants already have one or several chronic diseases;

- students mostly pursue passive selfpreserving behavior patterns, they underestimate influence exerted on a body by drugs, smoking, and alcohol [3, 12, 14];

- rational adaptation to student life is one of the most significant factors facilitating health preservation;

- first rank places in morbidity structure as per appealability to medical organizations (MO) belong to catarrhal diseases, nervous system diseases, sense organs diseases, and urogenital system diseases $[4,11]$;

- most researchers think that students' health is not studied enough (there is lack of authentic statistics in MO, and research takes place on regional and local level) [2];

- nowadays (under social and economic instability) asocial behavior grows, namely drug-taking and alcohol drinking; there is also increase in sexual diseases cases [1];

- a significant part of diseases is determined by life style, and positive features of self-preservation behavior (giving up bad habits) are a barrier to successful socialization among students [5];

- there are several reasons for students not attending lectures due to a disease: 1) catarrhal diseases $(69.3 \%)$; 2) traumas $(7.7 \%), 3)$ digestive organs diseases (3.6\%); besides, a number of students who belong to s special medical group in terms of physical activities grows annually [4];

- a specific weight of students attending HEEs and being disabled from their childhood also goes up;

- programs aimed at prevention of students' morbidity are created in HEEs, and health-preserving technologies are used in educational process [13].

Even a quick analysis of works dedicated to studying students' health reveals that the subject of our research is vital. 
Data and methods. On January 01, 2017 there were 3,568 students attending FSBEE Perm State Medical University named after Academician E.A. Vagner.

467 students of medical-prevention faculty were our research object; their number amounted to $13.08 \%$ of the total number of students (the sample was authentic). We made up a research program in the form of a questionnaire. The main part of the questions was aimed at studying students' selfassessment of their health, as well as at determining characteristics of behavioral risks in its formation.

We accomplished pilot research and questioned 77 third-year students of medicalprevention faculty, or $93.9 \%$ of all third-year students. We collected and processed 77 questionnaires in Biostat program. The sample amounted to $16.48 \%$ of total number of students at the faculty, and it proved the sample was representative. 20 male students and 57 female students took part in questioning. Ratio as per sex was equal to $1: 2.85$. Such ratio was characteristic for all years at this faculty. Average number of students as per years amounted to 77 and it also provided representativeness of our sample.

All the questioned students were divided into 2 groups: 1) those taking care of their health; 2) those who neglected their health. Each of these groups consisted of 4 sub-groups depending on self-assessment of their health:

- with "good health",

- with "satisfactory health",

- with "bad health",

- with "difficult to say" answer.

Results and discussion. To interpret the obtained results, we analyzed students' attitude towards their health allowing for discrepancies between groups and sub-groups. Specific weight of respondents, both males and females, who took care of their health amounted to 60.0 and $96.5 \%$ correspondingly. Specific weight of males taking care of their health was 1.6 times lower than females. Males assessed their health as "good" in $58.3 \%$ cases, as "satisfactory", in $16.7 \%$ cases, as "bad" in $0 \%$ cases. Each forth student had difficulty in assessing his health.
All female respondents took care of their health.

Assessment from the group of those not taking care of their health among males was as follows: "good health", 0\%; "satisfactory", $75 \%$; "bad", $25.0 \%$.

Structure of female respondents taking care of their health, was as follows: $47.3 \%$ respondents assessed their health as "good" and "satisfactory", $5.5 \%$ had difficulty in answering the question, and there were no "bad" assessments. Table 1 represents the whole data.

Table 1

Distribution of third year students of medicalprevention faculty as per attitude towards their health, self-assessment of their health,

\begin{tabular}{|c|l|c|c|}
\hline $\begin{array}{c}\text { Health } \\
\text { self-assessment }\end{array}$ & Sex & $\begin{array}{c}\text { Taking } \\
\text { care of } \\
\text { their } \\
\text { health }\end{array}$ & $\begin{array}{c}\text { Not taking } \\
\text { care of } \\
\text { their } \\
\text { health }\end{array}$ \\
\hline \multirow{2}{*}{ «Good» } & Males & 58,3 & 0 \\
\cline { 2 - 4 } & Females & 47,3 & 0 \\
\hline \multirow{2}{*}{ «atisfactory» } & Males & 16,7 & 75,0 \\
\cline { 2 - 4 } & Females & 47,3 & 0 \\
\hline \multirow{2}{*}{ «ad» } & Males & 0 & 25,0 \\
\cline { 2 - 4 } & Females & 0 & 0 \\
\hline \multirow{2}{*}{$\begin{array}{c}\text { «ifficult } \\
\text { to say» }\end{array}$} & Males & 25,0 & 0 \\
\cline { 2 - 4 } & Females & 5,4 & 0 \\
\hline
\end{tabular}

The obtained data reveal there are gender discrepancies in health self-assessment. It proves that men traditionally tend to over-estimate themselves. The results obtained by us coincide with the data obtained by other researchers [5].

The first and the main reason why all the students took care of their health was their wish to be physically stronger ( $41.7 \%$ males, $43.7 \%$ females). The second reason mentioned by females was health deterioration $(27.3 \%)$, and impact exerted by medical information was the third one.

Male respondents who didn't take care of their health outlined several reasons:

- unwillingness to set any limits for themselves $(25.0 \%)$;

- being sure no care guaranteed good health $(25.0 \%)$;

- absence of time (25.0\%); 
- other reasons $(25.0 \%)$.

We should point out that all the questioned students already had some ideas on influence exerted by environmental factors on their health (from the common hygiene course). Thus, a lot of male students thought that environmental factors and their own efforts had greater influence on their health. Bad habits were only mentioned by few students.

Female respondents' answers revealed that in their opinion health was formed under living conditions influence $(38.6 \%)$ and heredity $(19.3 \%)$, and each fifth mentioned bad habits.

The questioning revealed that $45 \%$ male students and $40 \%$ female students of the third year with quite different health self-assessment combined work and studies; $44.4 \%$ male respondents and $29.2 \%$ female respondents said their work had elements with mental and physical nature. Those were students who was included into groups with "good" and "satisfactory" health self-assessment.

Males with "good" health self-assessment were nervous and tired at their work in $22.2 \%$ cases; males with "satisfactory" health selfassessment mentioned the same in $33.3 \%$ cases. Female students suffered from much greater stress at work. Thus, females with "good" health self-assessment mentioned exhaustion in $50.0 \%$ cases, and with "satisfactory" health self-assessment, in $16 \%$.

We detected a certain correlation in respondents between health self-assessment and having bad habits. 20\% male students and 9\% female students smoked. A number of smoking males grew as their health self-assessment deteriorated (from 5\% among having "good" health to $10 \%$ of having "satisfactory" health). As for females, we observed decrease from 5.2\% ("good" health) to $3.5 \%$ ("satisfactory" health).

None of our respondents didn't take drugs at the moment of research. A part of the respondents were theoretically in drug danger as they were acquainted with drug-addicted people or they had previously taken psychoactive substances. We should pay attention to the fact that students often consumed alcohol (wine, beer, and strong spirits); it was mentioned by $90.0 \%$ males and $78.9 \%$ females.

We should also mention positive factors influencing respondents' health. Thus, $90.0 \%$ males and $93.0 \%$ females had physical training: - daily, $10.0 \%$ males and $12.3 \%$ females;

- often, 35.0 and $22.8 \%$ correspondingly;

- sometimes, $\quad 45.0$ and $\quad 57.9 \%$

correspondingly;

- never, 10.0 and $7.0 \%$ correspondingly.

All the third year students after annual medical examination at the physical culture department were divided into three groups depending on their health; 53.9\% males and $58.3 \%$ females attended the first (basic) group; $23.1 \%$ and $20.0 \%$ attended the second one; $23.1 \%$ and $21.0 \%$ attended the third group. Students' distribution in these groups coincided with their health self-assessment.

Studies in a HEE, especially a medical one, always involves great mental, physical, and emotional load. The questioning revealed that males and females had negative emotions:

- daily, $25.0 \%$ males and $8.8 \%$ females;

- often, 15.0 and $19.3 \%$ correspondingly;

-sometimes, 60.0 and $64.9 \%$ correspondingly;

- never, 0.0 and $7.0 \%$ correspondingly.

Suffering from negative emotions leads to stress and it influences health. Male students daily suffered from stress, 3 times more frequently, than female students.

To be successful in life, most students said they first of all needed such values as wealth, strong character, ability, and talent; the second place belonged to luck and education, health took the third place.

Females thought strong character was the most important, the second place belonged to support by close friends and relatives, and health occupied the third place.

Both males and females thought strong character to be the most important. This factor was very significant for students attending a medical HEE. It is impossible to be a successful student without string character and substantial efforts. And unsuccessful students can't count on free-of- 
charge education funded by state budget. Health as a value occupied only the third place in students' minds.

The questioning also revealed that students would like to receive authentic information which could help to preserve and to improve their health (table 2).

There are some common features in demands for knowledge in males and females. For example, all students considered it important to organize rational nutrition depending on their age, sex, and energy costs. This information can be obtained in lectures on "Nutrition hygiene", the fifth and sixth year. But in spite of total computerization students obviously were too lazy to look for such information on their own; nor had they time or willingness to apply for help and for an individual consultation to a medical prevention center. Thus we can state medical activity of the respondents was too low.

Table 2

Interest in information on health improvement shown by students as per information types and sex in rank order

\begin{tabular}{|l|c|c|}
\hline \multicolumn{1}{|c|}{ Information type } & Males & Females \\
\hline Eutrophy & 1 & 1 \\
\hline $\begin{array}{l}\text { Communication psychology and } \\
\text { stress prevention }\end{array}$ & 2 & 3 \\
\hline Healthy lifestyle & 3 & 2 \\
\hline Protection from adverse factors & 4 & 5 \\
\hline $\begin{array}{l}\text { Prevention of circulatory system } \\
\text { diseases }\end{array}$ & 5 & 6 \\
\hline Risk factors for your health & 6 & 4 \\
\hline
\end{tabular}

Respondents, regardless of their health state, were in the same manner interested in communication psychology and stress prevention. It can be explained by significant academic load and continuing adaptation of third year students. All respondents, regardless of their sex and health self-assessment, needed information on issues of healthy lifestyle creation and preservation, on circulatory system disease prevention, and organization of protection from adverse ecological factors.

The questioning revealed that need in knowledge on health preservation had many aspects and was formed consciously. Students took certain measures on diseases prevention on their own (table 3).

Table 3

Preventive measures structure, used by students to improve their health, depending on $\operatorname{sex}(\%)$

\begin{tabular}{|l|c|c|}
\hline Diseases prevention activities & Males & Females \\
\hline $\begin{array}{l}\text { Appealing to doctors in a polyclinic } \\
\text { in order to have preventive } \\
\text { examination, consultation, or } \\
\text { prophylactic medical examination }\end{array}$ & 25,0 & 25,0 \\
\hline $\begin{array}{l}\text { Taking vitamins in winter and spring } \\
\text { Preventive measures against flu } \\
\text { (vaccination, taking vitamins, } \\
\text { wearing masks, intensive airing) }\end{array}$ & 40,0 & 70,0 \\
\hline $\begin{array}{l}\text { Preventing acute conditions of } \\
\text { chronic diseases }\end{array}$ & 35,0 & 28,0 \\
\hline
\end{tabular}

Conclusions. Studying literature on the subject of our research and our own pilot questioning of third year students of medicalprevention faculty show that:

- students' health is a significant index of state which society intellectual potential has;

- specific weight of students, males and females, taking care of their health amounts to $60.0 \%$ and $96.5 \%$ correspondingly;

- health self-assessment being "good" is stated by $58.3 \%$ males and $100.0 \%$ females;

- there are gender discrepancies in assessing one's health in all sub-groups and motives of its preservation;

$-45.0 \%$ males and $40.0 \%$ females with varying health self-assessment combine studies and work;

- students tend to have bad habits, namely constant alcohol drinking and smoking;

- although information on diseases prevention is quite available in significant volumes, students don't try to use it in due time and to preserve their health;

- irrational nutrition, insufficient physical and medical activity are the main problems of medical students' lifestyle. 


\section{References}

1. Andriyanova O.V. Organizatsiya raboty po formirovaniyu zdorovogo obraza zhizni i meditsinskoi profilaktike v Sverdlovskoi oblasti [Organizing activities aimed at forming healthy lifestyle and medical prevention in Sverdlovsk region]. Sistemnaya integratsiya v zdravookhranenii: elektronnyi zhurnal, 2011, no. 2, pp. 49-66 (in Russian).

2. Artyukhov I.P., Yakovlev T.V. KrasGMU - VUZ zdorovogo obraza zhizni, nauchnyi proekt [KrasSMU - University of the healthy lifestyle, research project]. Krasnoyarsk, 2011, 156 p. (in Russian).

3. Valentinovich L.I., Domrachev E.O. Sotsial'no-gigienicheskaya kharakteristika studentov meditsinskogo kolledzha [Social and hygienic characteristics of students attending medical college]. Profilakticheskaya meditsina, 2010, no. 3, pp. 59-62 (in Russian).

4. Medvedkov V.D., Medvedkova N.I., Ashirova S.V., Sil'dushkin I.V. Zdorov'e detei, prozhivayushchikh na ekologicheski neblagopriyatnykh territoriyakh [Health of children living in environmentally adverse territories]. Pedagogiko-psikhologicheskie i mediko-biologicheskie problemy fizicheskoi kul'tury i sporta, 2010, no. 2, pp. 68-72 (in Russian).

5. Zdorov'e studentov: sotsiologicheskii analiz [Students' health: sociological analysis]. In: I.V.Zhuravleva ed. Institut sotsiologii RAN. Moscow, 2012, 252 p. (in Russian).

6. Kartysheva S.I., Popova O.A., Grosheva E.S. Samootsenka zdorov'ya i obraza zhizni studentov pedagogicheskogo universiteta [Self-assessment of health status and lifestyle among students of pedagogical university]. Gigiena i sanitariya, 2015, vol. 94, no. 9, pp. 18-20 (in Russian).

7. Kicha D.I., Panachina M.I. Istoriya sotsial'no-gigienicheskikh issledovanii studentov [Students: history of social and hygienic examination]. Sovetskoe zdravookhranenie, 1987, no. 7, pp. 63-66 (in Russian).

8. Klyachko T. Vysshee obrazovanie: bol'she, luchshe ili deshevle [Higher education: more, better or cheaper]. Demoskop, 1-24 Jan, 2016, no. 669-670. Available at: http: //demoscope.ru/weekly/2016/0669/tema01.php (12.10.2016) (in Russian).

9. Lebedeva N.M., Osipova E.V. Vzaimosvyaz' sotsiokul'turnogo konteksta i motivatsii lichnosti s povedeniem i ustanovkami studentov po otnosheniyu k svoemu zdorov'yu [Correlation between socialcultural context, personal motivation and students' behavior and attitudes towards their health]. Al'manakh sovremennoi nauki i obrazovaniya, 2011, no. 5, pp. 97-106 (in Russian).

10. Mironov S.V. Sostoyanie zdorov'ya rossiiskikh i inostrannykh studentov meditsinskogo VUZa i puti uluchsheniya meditsinskogo obsluzhivaniya: avtoref. dis. ... kand.med.nauk [Health state of Russian and foreign students attending medical HEE and ways to improve their medical care: abstract of a thesis ... candidate of medical sciences]. Moscow, 2014, 26 p. (in Russian).

11. Mironov S.V., Ivanov A.A. Mediko-sotsial'noe issledovanie samootsenki zdorov'ya i obraza zhizni studentov vysshego meditsinskogo uchebnogo zavedeniya [Medical and social examination of health and lifestyle self-estimation given by students attending medical HEE]. Byulleten' Severnogo gosudarstvennogo meditsinskogo universiteta, 2011, no. 1, pp. 241-242 (in Russian).

12. Osipova E.V. Sotsiokul'turnye razlichiya motivatsii zdorov'e-sberegayushchego povedeniya: dis. ... kand.psikh.nauk [Social and cultural differences of health-preserving behavior motivation: abstract of a thesis ... candidate of medical sciences]. Moscow, 2011, 226 p. (in Russian).

13. Proskuryakova L.A., Lobykina E.N., Burnysheva T.V. Struktura programmnogo kompleksa «Zdorov'e studentov» i ego znachenie v podderzhke ikh zdorov'ya (na primere Yuga Kuzbassa) [The structure of software complex "Student health" and its significance in their health support (as exemplified by the south of Kuzbass)]. Zdravookhranenie Rossiiskoi Federatsii, 2016, vol. 60, no. 1, pp. 53-55 (in Russian).

14. Gur'yanov M.S., Kamaev I.A., Ivanov A.A., Mironov S.V. Rasprostranennost' kureniya sredi meditsinskikh rabotnikov [Prevalence of smoking among the medical workers]. Vestnik Rossiiskogo universiteta druzhby narodov. Seriya: Meditsina, 2009, no. 4, pp. 511-515 (in Russian).

15. Kamaev I.A., Gur'yanov M.S., Mironov S.V., Ivanov A.A. Sotsiologicheskoe izuchenie zdorov'ya i obraza zhizni studentov meditsinskoi akademii [The sociological survey of health and lifestyle among medical academy students]. Problemy sotsial'noi gigieny, zdravookhraneniya $i$ istorii meditsiny, 2010, no. 1, pp. 24-27 (in Russian). 
Govyazina T.N., Utochkin Yu.A. Assessment of basic behavioural risks concerning health of students attending medical university. Health Risk Analysis, 2017, no. 1, pp. 80-86. DOI: 10.21668/health.risk/2017.1.09.eng

Received: 13.11.2016

Accepted: 18.03 .2017

Published: 30.03.2017 